\title{
Comprehensive Test Ban (CTB) Reviews
}

\author{
J. K. Landauer
}

\section{DISCLAIMER}

This report was prepared as an account of work sponsored by an agency of the United States Government. Neither the United States Gnvernment nor any agency thereof, nor any of their employees, makes any warranty, express or implied, or assumes any legal liability or responsibility for the accuracy, completeness, or usefulness of any information, apparatus, product, or process disclosed, or represents that its use would not infringe privately owned rights. Reference herein to any specific commercial product, process, or service by trade name, trademark, manufacturer, or otherwise does not necessarily constitute or imply its endorsement, recommendation, or favoring by the United States Government or any agency thereof. The views and opinions of authors expressed herein do not necessarily state or reflect those of the United States Government or any agency thereof.
RECEIVED
JAM 991997
OSTI

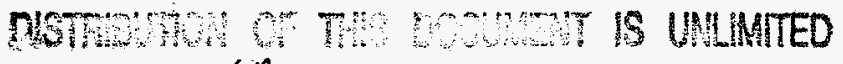
May 7, 1970

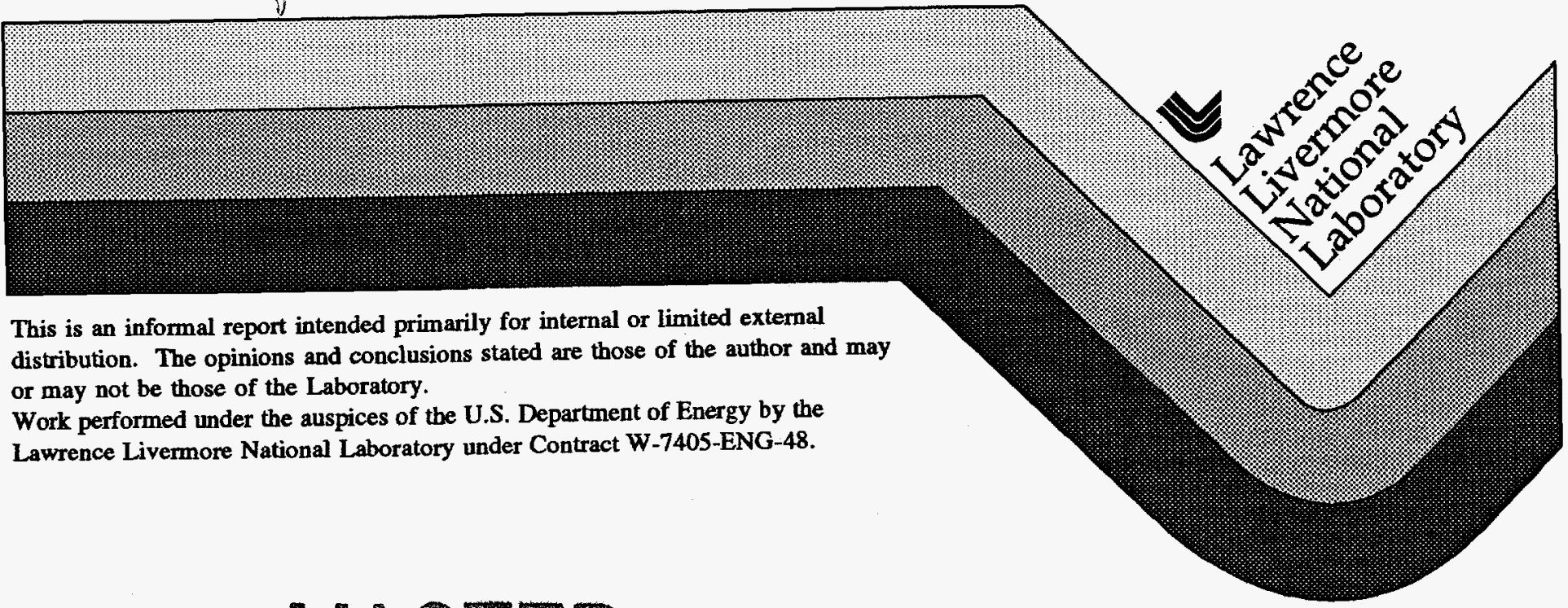




\section{DISCLAMMER}

Portions of this document may be illegible in electronic image products. Images are produced from the best available original document. 

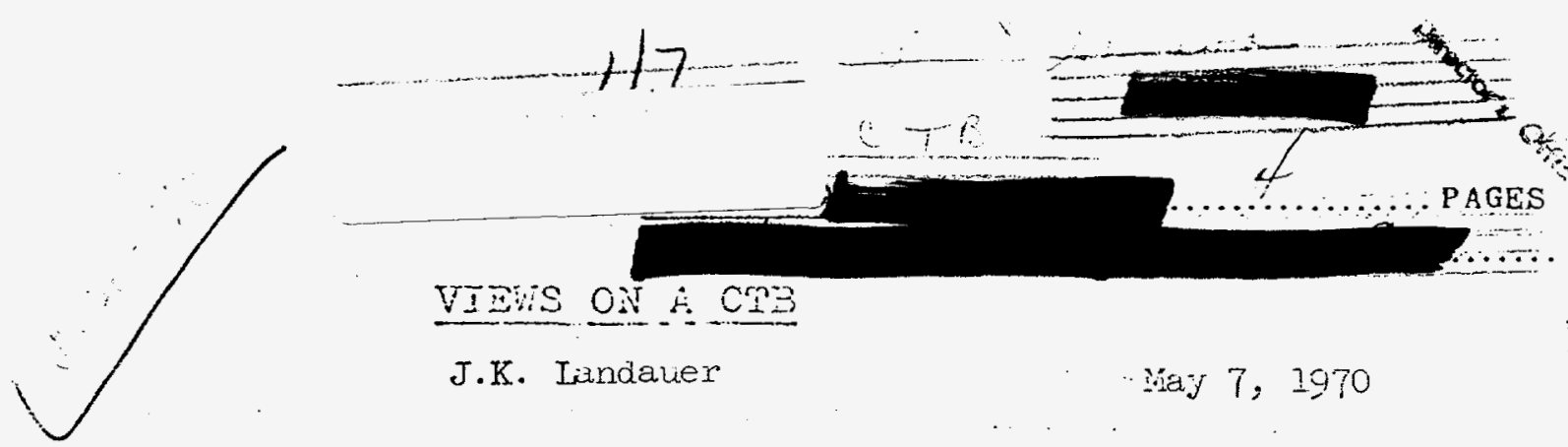

J.K. Liandauer

Y.aj 7,1970

I have read tith intenast yechotse's papen on Seicuic Verification. I think it is a fair report of the status of

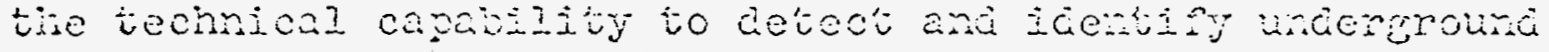

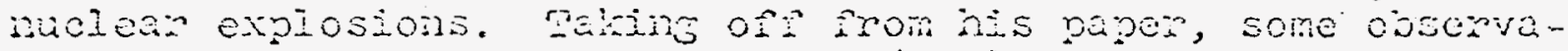
tions on a comprehersive test bar (CDe) vishe to be macie. Hith the facts that I have on hand, I can convince nyself that here are no really pressing techitcal reasons to conciude a Cra,

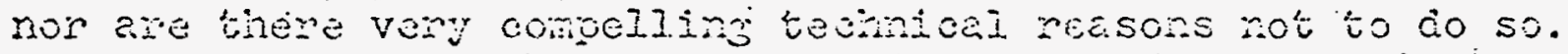
periaps there are othen, more vaijd reasons for or arjinst a

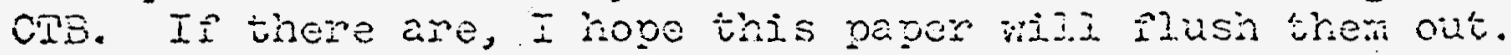

A reason for concluating a Che is sata to be that"it

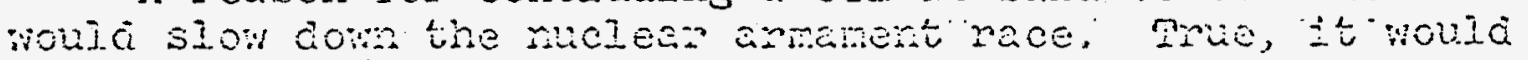

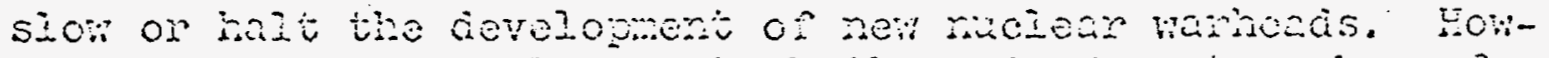

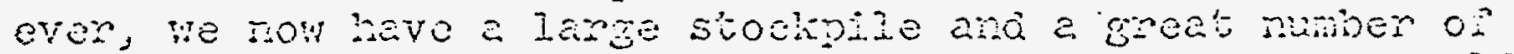

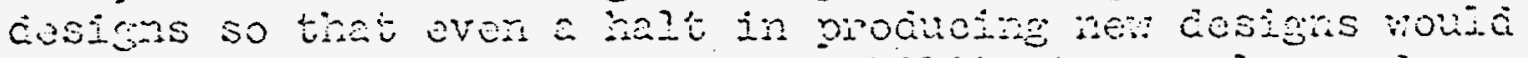

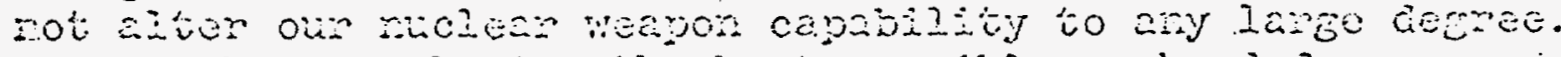

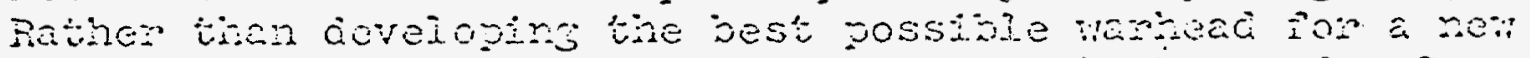

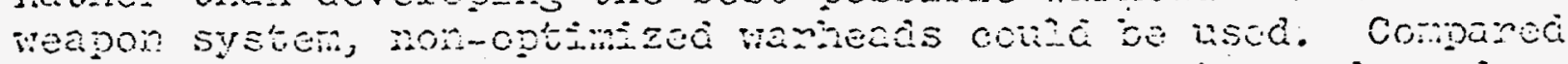

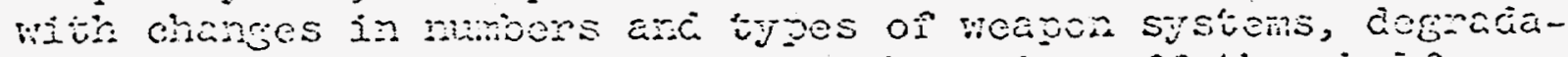

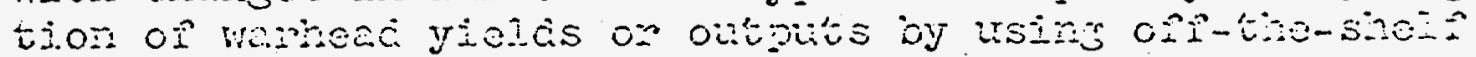

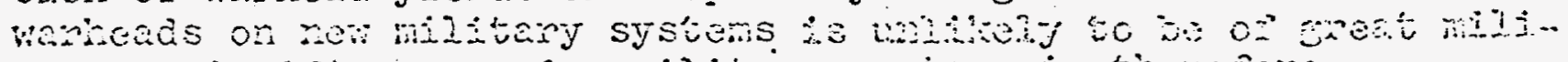

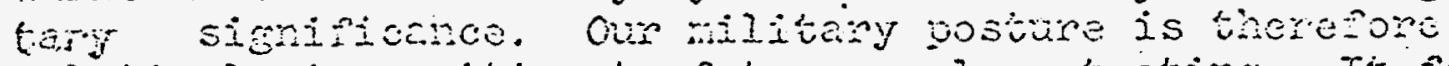

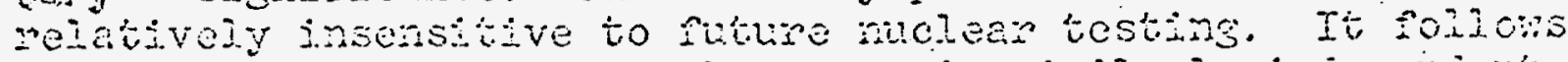

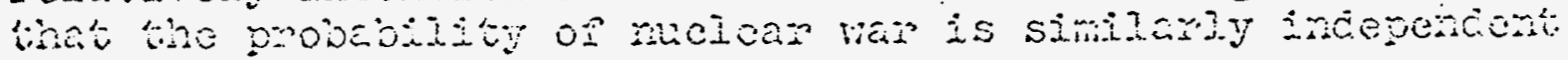
ô. Tuture nuolda: tost activitios.

A second roason to stop wucican besting is thet no cond

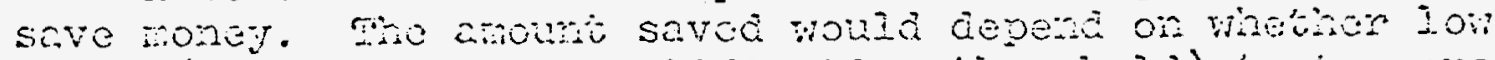

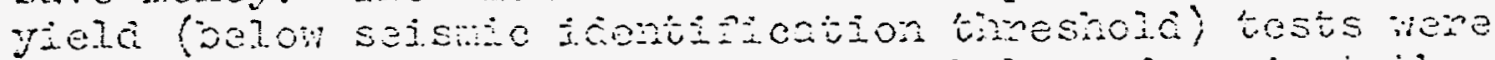
allowod. rest savings aiso must be balanced arginst the costo

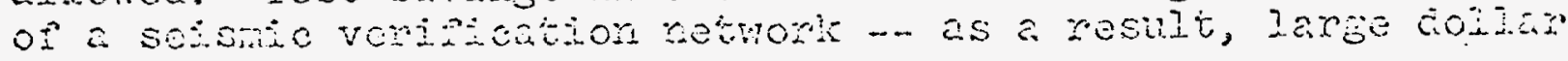
savings ane unizkeiv.

A thind reeson to stop testing nint be put romand oy

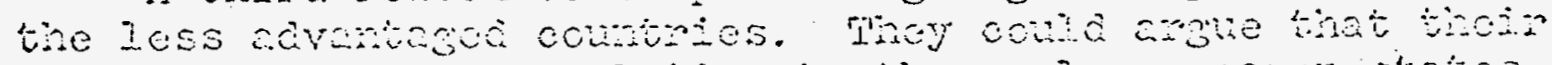

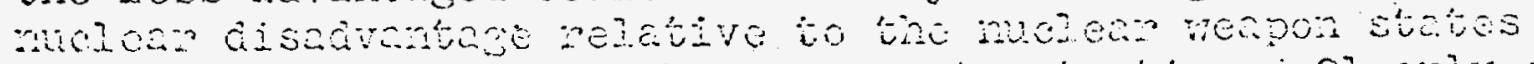

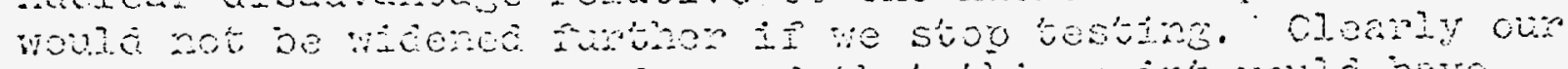

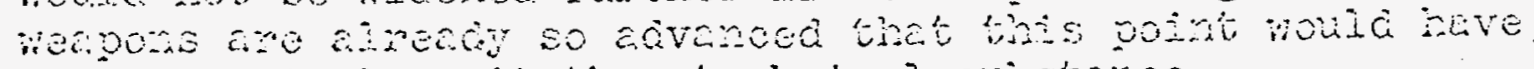

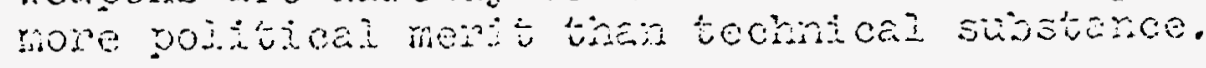


A founth reason advanced to discontinue testing is triat it is poinuting the earth. In foct, exept for pibustare excavation tests, the amount of rajioactivity from urideround tests escaving to the atnospiene is guite amail. It is curronty regidgible comparea vitin other somces of adidation. The

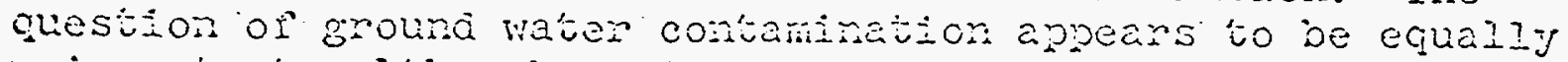
unimportante, although erviromentalists certainiy will argue this point.

The reasons against a treaty are tinat (I) re could not verify the condition of our nuclear stochpile; (2) otier countries might surreptitousiy nake simpicari inprovenents

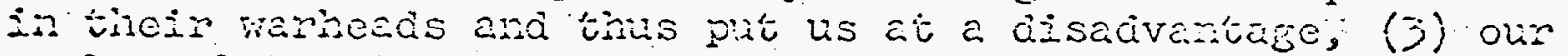
nuclear laboratories woula lose their sood people and thejr

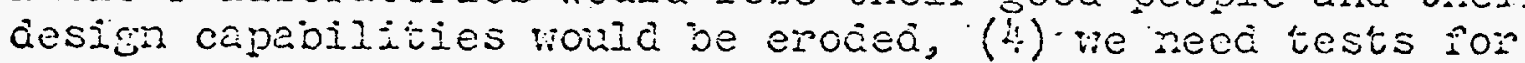
veapon systems now on the dicurnes boards, and (5) in terns of the overaji weapon systen, nulear testing to provide...

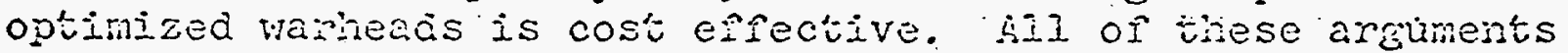
mahe sone sense, but they do not seen very strong to me.

As far as stoclpile verificetion boes, we have"haraij ever needed such tests. Our need in the future is jot íkely to be greater than in the past.

On the angunent that the other sice misht nake signipicant warisead inorovements though checting, I dort to beijeve that the sont ồ inprovenents that can be mabe in fission on Iusion explosives vould realiy alter the balance or po:rea ron exsiting. To leac crederce to that point, the saip siucies that I kinow of and dases on mubeas of reapon deljvery sysuens

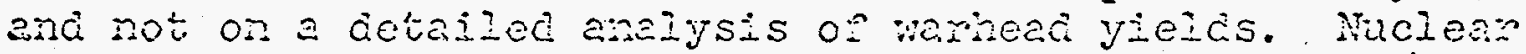
design efrort oven the dast years has led to 10 oi 20\% juipove-

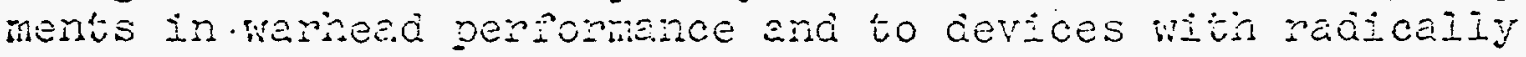

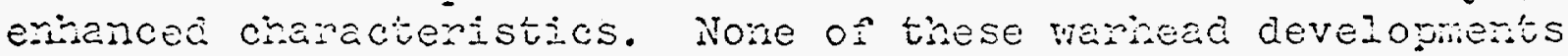
have really alverea our dejoyed reppon capability in a nejon

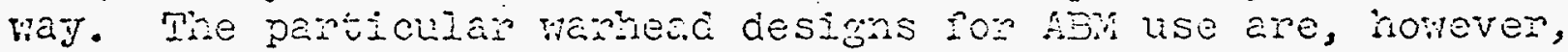
the result of recent huclear testing. Winont the ope thized

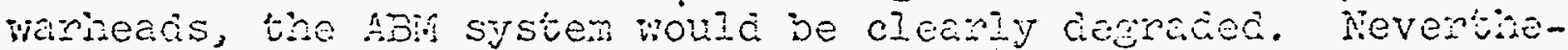
less, one conta argue that without hew ranheac designs, an Asin systen using exesting waheads wonda stili have been developeci.

Perhaps the "avating"apgunent aganst a treaty could be

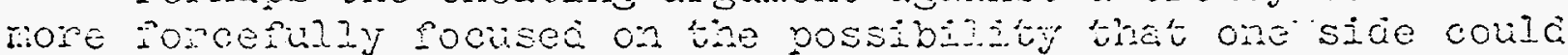

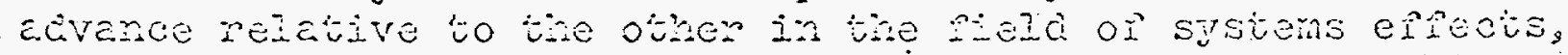

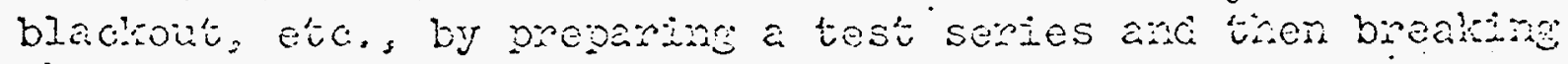
bise treaty. 
If our laboratories lose their best desizners and the enewy petains good desigrers, I cannot see how the dalance of poner is izkely to be altered. The next weapon breakthirough, as has happened in the past, is most ilkely to be generated by non-development work at some unfversity laboratory.

The need for tests to supply warheads for ursent new systens (Iike the ADH) has cecreased with the successiul series wich is rearing completion. The Abu wanhead for Spartan wili be completed berore any $\mathrm{C} B$ colila non de nerotiated.

The fifth argument against cessation ô testinf is certainly vaita. If there is no good resson to give up testing, and it the US needs new weapon systens, then an optimized wariead rather than some make-co, less epricient nocei ofi the sheli, makes good military serise. The fact that testing dolians are small compared with weapon system costs rakes the development ara lise of the best possible warhead a cost effective (or appioximately so) procedure.

Phus, it seems to me that the tecintcai argunents for or against a CTB are not compelling. (Hom these arguments appear to other observers is another question.) Beside the question as to whetier it is desinajie or not to have a CNB, thene are some detaijs reiative to a seisuicaily verizied trirashoia treaty, minich needi answers.

One question neecing an ans:ler is hom will bests ie treated belon the seisnic identiricetion threshold? rinet is, are lon-yieid tests banied on ailoned? Many iriterestins toves cond jo executed within a magnitude 4 jimit

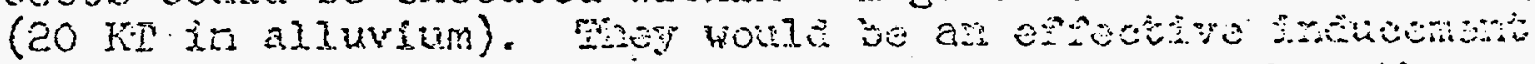
to reep sood people at the laboratontes. If you ban these tests, you achieve a nore concrete discmament status and yoli. might save sone money. Joneven, national neans of verification would cleariy be inclequate to monter such a ban. It a moretronin on lon yiela testos was concluded, and if one side continuea to test small devices in a cianciestirie namer, thie gatins for trats stie are not itkely to be very great. They could get a littie information on high yield device periomm ance; they coula keep their goou neapon cesignems interestied; aid they could continue development ot ion yiela veaponis în tactical or ABM applicetions. By arguments sinilar to trose minch I used eanlier, none op these develoonentus is likely to make a large change in the balance of porvis. Neventheless. I rouja expect quite a few peopie (e.3., Senators) to renain 
uncouvineed that asymotries in testing colid be toleratea. Ir you don't ban lou yield tests, you haven't gathed very much in a ajsanmanch sense by a complicabed and expensive threshoia test ban treaty hitich conld ever jead, trirough slispicior, to a worsening oi interiational relations.

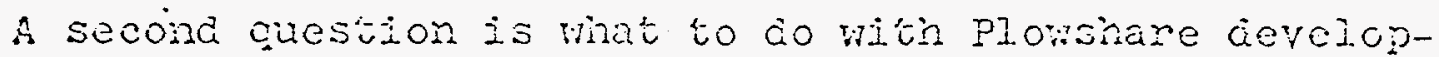
ment tests. I cannot conceive or any simple way to ruarunice that sucir tests rould not be veapon related. Since trene could be relatively large numbers of these, a signiricant possibility For weapon develownent wouid exist. I thirk the chances por cheating in this area are greater than oriened by decoupling, eartiquake maning, or otiser spooing techinques. II ro contiols can be instituted to giand against reapon development, plcisheise. developnent could be jiven up (micin seons a large crice to paj), or weajon cevelopnent potentialities would have to be ionorea.

Fron ali of the above, ny conciusions are that we shouza do some hend thinking about a comprahensive test ban treaty. rhe pressures ior such a treaty are likely to increase greaty in the next year or so and we should hot de caugrit unpreparec.

\section{J. K. Lañâuer $(4 / 22 / 70)$}

Distribution:

Cy IA A. Blackwell - SCL

$2 A$ F. Eby

$3 A$ L. Germain

4A W. Feckrote.

$5 A$ J. Landauer

B Series Distribution - May 8, 1970

Cy IB R. E. Batzel

$2 B$ A. T. Biehl

3B A. C. Haussmann

4B H. L. Reynolds

$5 \mathrm{~B}$ J. W. Rosengren

$6 B$ G. C. Werth

"C" Distribution - 5-20-70

IC M. M. Mau

IC File 